\title{
The Best Counseling Methods for Fishermen in Overcoming Coral Reef Ecosystem Damage in Pasawaran Regency
}

\author{
Freddy Johanis Rumambi', Adri Frans Assa ${ }^{2}$
}

${ }^{1}$ freddyrumambi@gmail.com, ${ }^{2}$ adrie.assa@ukrida.ac.id

\begin{abstract}
This study was conducted to determine the effect of extension methods and achievement motivation on knowledge about the impact of damage to coral reef ecosystems. This research was conducted using a mixed-method that is quantitatively supported by qualitative data from interviews to achieve this goal. Quantitative method used for fishers in Padang Cermin Subdistrict, Pasawaran Lampung Regency with $n=60$ using 2X2 factorial. While the Qualitative Method conducted interviews with several Fishermen, Padang Cermin District Head, Sanggit Village Head, Community Social Institutions (NGOs) Concerned with Lampung Environmental Reform and Development and SatuanMarkas Officer at Pangkalan TNI AL Lampung.
\end{abstract}

Keywords:

ecosystem, coral reef, counselling, motivation to succeed, fishermen

Article Received: 18 October 2020, Revised: 3 November 2020, Accepted: 24 December 2020

\section{INTRODUCTION}

The coral reef ecosystem spread throughout Indonesian waters is estimated to be approximately $50,000 \mathrm{~km}^{2}$. The coral reef ecosystem and all the life contained therein are priceless natural resources (Burkepile \& Hay, 2018). Coral reef ecosystems are typical tropical ecosystems with very high organic productivity and very high biota biodiversity (Lesser, 2004). The productivity of coral reef ecosystems is high, and if it functions optimally, it can increase fishery production, so that it will indirectly provide both social and economic benefits for coastal village communities, mostly fishermen and Indonesian society in general(Adriman et al., 2012). Coral reef ecosystems are typical tropical ecosystems with very high organic productivity and very high biodiversity of biota. The high organic productivity (primary) allows these waters to become a place for spawning (spawning ground), care (nursery ground) and foraging (feeding ground) of some fish(Van Oppen et al., 2015). Besides, the coral reef ecosystem as a tropical seabed ecosystem whose community is dominated by lime-producing marine biota functions among others: As food and other resources, Source of materials, Sources of pharmaceutical and industrial materials other chemistry, tourism and recreation purposes, education and scientific development, biological support (e.g. breeding and feeding for offshore fish), support in case of the food crisis, and coast protection from erosion(Fathurrohmah et al., 2013).

Indonesia's population continues to experience growth so that the scarcity of natural resources on land forces humans to look for other alternatives. One of the alternatives is natural resources in the sea(Nadiarti et al., 2012). Human activities to exploit the potential of natural resources in the sea, especially in coastal areas, often directly or indirectly damage the coral reef ecosystem(Darling et al., 2019). This is reflected in the level of marine pollution, overfishing symptoms, physical degradation of the main coastal habitats (coral reefs, mangroves, etc.), as well as conflicts over the use of coastal areas in densely populated areas or high levels of development (industry) (Narwan, 2019).

Threats to the survival of coral reef ecosystems can come from natural and human factors(Gittenberger et al., 2015). Damage due to natural factors, among others: physical, chemical and biological. Physically, among others, it is 
caused by storms such as typhoons, earthquakes, and El Nino. Chemicals such as pesticides, detergents, fertilizers, oils, heavy metals. Damage due to biological factors, such as predators for coral polyps, such as thousand feathers (Acanthasterplanci), and coral reef-eating fish.

Meanwhile, human-caused or anthropogenic damage includes, among other things, the use of fishing gear that endangers coral life, such as the use of Muro Ami, explosives, toxic materials, coal mining, and residual waste, both from industrial and household activities on land(Planes et al., 2019). This incident caused many coral reefs to be unable to recover from the damage and loss of national assets in decreasing productivity and the diversity of marine biodiversity they have. According to a research report from the Research and Development Center for Oceanology (P3O) LIPI in 1996 , out of $50,000 \mathrm{~km}^{2}$ of coral reefs in Indonesia, only $5.3 \%$ of which are in excellent condition, $21.7 \%$ good, $33.5 \%$ moderate and The other $39.5 \%$ are in a damaged condition(Dirhamsyah, 2018). Damage to coral reef ecosystems will indirectly affect changes in the structure and structure of the social, economic, and cultural lives of fishing communities. Fishers work in the business of aquatic animal resources, especially looking for fish as a source of life(Ilahude\& Gordon, 1996).

However, fishers in the context of exploiting the potential of natural resources in coastal areas, either directly or indirectly, often damage coral reef ecosystems(Adriman et al., 2012). One of the reasons why fishers, directly or indirectly, often damage coral reef ecosystems is a lack of knowledge about coral reef ecosystems and their damage. A strong foundation is needed to anticipate this and guide fishers to manage coral reef ecosystem resources (Wardhani, 2011). The management strategy covers the use, maintenance, and development and includes substantial institutional and legal aspects that ensure sustainable management of coral reef ecosystems(Nasution, 2017). Besides that, the management of coral reef ecosystems must be directed at ecosystem management, where fishers have an essential role in the management. In this case, fishers need to be equipped with knowledge and information about maintaining coral reef ecosystems' balance.

\section{LITERATURE REVIEW \\ Coastal Communities}

Management of fisheries and coastal resources is one of the essential agendas in current national development policies. The attention of the Ministry of Fisheries and Marine Affairs (KKP) of the Republic of Indonesia towards maritime/marine development has not improved the quality of life of coastal communities, mostly fishermen. The low standard of living in coastal communities and limited access to assets and financial resources is a significant problem for fishers (Yasir et al., 2017). Coastal communities have distinct life, face directly to the challenging ecosystems and livelihoods that depend on coastal and marine resources. Coastal communities, mostly traditional fishermen, are still entangled by poverty and underdevelopment problems. The community and fishermen's coastal conditions are not yet free from the problems faced, including limited access to capital resources and communication weakness in bridging the gaps that occur (Wallace et al., 2014).

Coastal communities have distinct life, face directly to the challenging ecosystems and livelihoods that depend on coastal and marine resources (Petzold, 2018). Coastal communities, mostly traditional fishermen, are still entangled by poverty and underdevelopment problems. The community and fishermen's coastal conditions are not yet free from the problems faced, including limited access to capital resources and communication weakness in bridging the gaps that occur (Sutton-Grier et al., 2015). Coastal communities live on the thin strip of land or water along the fluctuating line where the sea meets the land. Trying to define otherwise either this group of people or delimiting the resources they depend on is an elusive task (Mohan, 2005). 
The coastal zone may be defined "ecologically" as the land area influenced by the sea; politically by some arbitrary distance inland from high tide level; or socially as the area occupied by people dependent on the sea for livelihood (Farhan \& Lim, 2012). For any means except setting an arbitrary distance, the exact extent of the coastal zone defies rigorous definition due to the interconnectedness of ecosystems and human activities in this productive strip between land and sea (Spalding et al., 2014).

Aspects of the nature of the overall coastal system, including people and their coastal environment, will be discussed. It is dangerous to generalize, but some aspects seem to be common enough to warrant comment. Understanding the complex system's nature can help the outsider better work with people who are part of the system and may not consciously think about the overall system. This should help the outsider contextualize work with coastal communities and probe beneath the surface (Thanigaivel et al., 2016).

This paper evaluated social driving factors supporting coral reef restoration in Pemuteran. The impacts of the project will be examined by looking at the community's perceptions of them. We evaluated the major driving forces boosting social awareness and increasing participation leading to the project's success. Other coral reef restoration and conservation projects can use this example to improve their future project planning

\section{The Best Counseling Methods}

According to the American Counseling Association (2015), counselling is defined as, "a professional relationship that empowers diverse individuals, families, and groups to accomplish mental health, wellness, education, and career goals."Counselling involves helping people make needed changes in ways of thinking, feeling, and behaving, and is a goal-based collaborative process, involving a non-judgmental, supportive counsellor who works with a client in telling his or her story, setting achievable goals, and developing strategies and plans necessary to accomplish these goals(American Counseling Association, 2015). For some people, this process takes a small amount of time, in some cases, as little as one or two sessions; for others, the process may last longer (Gelso, 2015). A significant part of counselling is confidentiality, which means that the information discussed in the session will be accessible only by you and your counsellor, with a few exceptions. Please see Client Confidentiality for more detail.

The extension is a learning process for main actors and business actors to be willing and able to help and organize in accessing market information, technology, capital, and other resources to increase productivity, business efficiency, income and welfare, and increase awareness in preserving environmental functions. The extension comes from the word "slush" which means "torch" or "lamp" or "which gives light". With counselling, it is expected that there will be an increase in knowledge, skills and attitudes. Knowledge is said to increase when there is a change from not knowing to know and those who already know to know better. Skills are said to increase when there is a change from being unable to do a useful job. Attitudes are said to increase when there is a change from being unwilling to take advantage of the opportunities created (Ponticelli \& Graziani, 2012).

\section{RESEARCH METHOD}

The method used in this research is the mixed method, namely quantitative methods supported by qualitative data, in the quantitative method, namely by conducting experiments on two groups of subjects, namely the experimental and control groups. Since the research hypothesis is an interaction hypothesis, the most appropriate design is the 2 X 2 factorial design (Fetters et al., 2013). The extension method treatment variables were classified into demonstration methods and lecture methods, while the motivational attribute variables were successfully classified into strong 
and weak among fishers in Padang Cermin subdistrict, Pasawaran district. The population in this study were fishermen in Pasawaran District (Apuke, 2017).

The sample was fishermen in Padang Cermin district. Determination of the sample is carried out in the following steps: (1) Determining the location of the research village randomly simple (simple random sampling) of coastal villages, in Padang Cermin District which has the same characteristics, (2) The selected village is then selected Randomly, as many as 90 fishermen to measure the level of motivation to succeed through a questionnaire that has been prepared, (3) Questionnaires that have been answered by the respondents are then evaluated by the researcher. The evaluation aims to find respondents who have strong success motivation and respondents who have weak success motivation. From the results of the evaluation, it was found that 60 fishermen (respondents) were the research sample, consisting of 30 respondents who had strong motivation to succeed and 30 respondents who had weak success motivation, (4) 30 respondents who had strong success motivation and 30 respondents who had success motivation Weak is then simple randomly drawn to occupy an extension class using the demonstration method or the lecture method. Data collection was carried out at the end of counselling through test sheets distributed to respondents (Voleti, 2019).
The score is given for each test sheet, based on the number of items answered correctly (Paradis et al., 2016). The correct answer gets a score of 1 and a false 0 . The scores obtained are arranged in tabular form. Knowledge data about the impact of damage to coral reef ecosystems in this study were obtained through a self-made instrument in the form of test sheets with multiple-choice questions. In this study, a package of the same instruments was used, namely measuring fishermen's knowledge about the impact of damage to coral reef ecosystems, both those with a healthy motivation level and those with a weak success motivation level, both those who received counselling using the demonstration method or the lecture method. For qualitative data, the researchers conducted interviews with several fishers, the Head of the Padang Cermin subdistrict, the Head of Sanggit Village, the Community Social Institution (NGO) Caring for Environmental Reform, and Lampung Development and Maritime Potential Officials at the Indonesian Navy Base in Lampung.

\section{RESULTS AND DISCUSSION}

\section{Results}

In general, this study shows that the demonstration method is better than using the lecture method; this can be seen from the table below. General research data can be seen in table 1 ,

Table 1. Description of Knowledge About Data Impact of Damage to Coral Reefs Ecosystems

\begin{tabular}{ccccc}
\hline MET. EXTENSION & $\begin{array}{c}\text { DEMONST } \\
\text { RATION } \\
\text { MOTIVATION }\end{array}$ & $\begin{array}{c}\text { LECTURE } \\
\text { METHOD } \\
\text { SUCCESSFUL }\end{array}$ & $\begin{array}{c}\text { (A2) } \\
\text { (A1) }\end{array}$ & $\Sigma$ \\
\hline Strong & $\mathrm{n}$ & 15 & 15 & 30 \\
(B1) & $\mathrm{x}$ & 26,27 & 22,07 & 24,1 \\
& $\mathrm{~s}$ & 3,49 & 3,63 & 7 \\
Weak & $\mathrm{n}$ & 15 & & 4,10 \\
(B2) & $\mathrm{n}$ & 20,53 & 20,80 & 30 \\
& $\mathrm{~s}$ & 3,41 & 3,32 & 20,6 \\
& & & & 3,31 \\
\hline
\end{tabular}




\begin{tabular}{ccccc}
\hline & $\mathrm{n}$ & 15 & 15 & 60 \\
$\mathrm{~N}$ & $\mathrm{x}$ & 23,4 & 21,43 & 22,4 \\
& $\mathrm{~s}$ & 4,47 & 3,48 & 1 \\
& & & & 4,09 \\
\hline
\end{tabular}

Information:

$\mathrm{n}=$ Many samples

$\mathrm{x}=$ Average score of knowledge on the Impact of Damage to Coral Reefs Ecosystems $\mathrm{s}=$ Standard deviation

The table above explains that the demonstration method is more successful than the lecture method. In the demonstration method with strong motivation (B1), the knowledge score on the impact of damage to coral reef ecosystems was 26.27, while in the lecture method the mean score of knowledge on the impact of damage to coral reef ecosystems was 22.07. Meanwhile, the motivation to succeed is weak (B2), it shows that the demonstration method, the mean score of the resulting data is 20.53 , while in the lecture method the mean score of knowledge on the impact of damage to coral reef ecosystems is 20.80 . motivation to study the impact of damage to coral reef ecosystems.

The results of data analysis with the two-way ANOVA score of knowledge about the impact of damage to coral reef ecosystems can be seen in table 2,

Tabel 2.

Results of the Two Pathways of Knowledge About Variance Analysis Impact of Damage to Coral Reefs Ecosystems

\begin{tabular}{|c|c|c|c|c|c|c|}
\hline \multirow{2}{*}{$\begin{array}{c}\text { Sumber } \\
\text { Variance }\end{array}$} & \multirow{2}{*}{ DF } & \multirow{2}{*}{ JK } & \multirow{2}{*}{ RJK } & \multirow{2}{*}{ Fh } & \multicolumn{2}{|l|}{ Ft } \\
\hline & & & & & $\mathbf{0 , 0 5}$ & $\mathbf{0 , 0 1}$ \\
\hline Between Rows (A) & 1 & 183,75 & 183,7 & 15,267 & & \\
\hline Between Columns (B) & 1 & 58,02 & 5 & $* *$ & 4 , & 7,0 \\
\hline Interaction $(\mathrm{AxB})$ & 1 & 74,82 & 58,02 & $4,82^{*}$ & 00 & 8 \\
\hline & & & 74,82 & $6,216^{*}$ & & \\
\hline AntarKelompok & 3 & 316,59 & - & - & - & - \\
\hline ------------------------ & --- & ------------ & ------- & & & \\
\hline- & -- & & -- & & & \\
\hline DalamKelompok & 56 & & & & & \\
\hline Total Direduksi & 59 & & - & - & - & - \\
\hline ------------------------- & --- & ------------- & & & & \\
\hline- & -- & 30150,417 & & & & \\
\hline Rerata & 1 & 31141 & & & & \\
\hline Total & 60 & & & & & \\
\hline
\end{tabular}

\section{*: Signifikan}

**: Sangatsignifikan

The results of the two-way ANOVA in Table 2 above show: (1) The null hypothesis (H0) which states that the average knowledge about the impact of damage to coral reef ecosystems provided by counselling using the demonstration method is not different from the lecture method is rejected $(\mathrm{Fh}>\mathrm{Ft})$.

The difference in average knowledge of the impact of damage to coral reef ecosystems using the demonstration method has a very significant 
value, (2) The null hypothesis (H0) which states that the average knowledge of the impact of damage to coral reef ecosystems on fishers who have strong motivation to provide information using the demonstration method successfully has no difference or the method is rejected $(\mathrm{Fh}>\mathrm{Ft})$. In other words, there is a difference in the mean Knowledge about the impact of damage to coral reef ecosystems on fishers who have a strong motivation to succeed who are given counselling using the demonstration method with the lecture method. Problem formulation (3) The null hypothesis (H0) which states that the average knowledge about the impact of damage to coral reef ecosystems on fishers who have the weak motivation to succeed who are given counselling using the demonstration method is not different from the lecture method is rejected $(\mathrm{Fh}>\mathrm{Ft})$. In other words, there is a difference in the mean Knowledge about the impact of damage to coral reef ecosystems on fishers who have weak motivation to succeed who are given counselling using the demonstration method with the lecture method, (4) The null hypothesis (H0) states that there is no interaction between extension strategies and motivation. Successful in its influence on knowledge of the impact of damage to coral reef ecosystems were rejected ( $\mathrm{Fh}>\mathrm{Ft}$ ). Thus, it can be concluded that there is a significant interaction effect between extension strategies and successful motivation on knowledge of the impact of damage to coral reef ecosystems. The effect of the interaction between counselling and success motivation, and (5) The null hypothesis (H0) which states that there is no difference in mean knowledge about the impact of damage to coral reef ecosystems on fishers who have strong motivation to succeed and fishermen who have weak motivation to succeed are rejected $(\mathrm{Fh}>\mathrm{Ft})$. In other words, there is a difference in the average knowledge about the impact of damage to coral reef ecosystems on fishers who have a strong motivation to succeed with those who have a weak motivation to succeed.

\section{Summary of Tukey Test Results}

In connection with the difference between the effect of extension methods on knowledge of the significant impact of coral reef ecosystem damage, the analysis technique was continued with the Tukey test (Putrawan, 1990: 101-102). The results of the Tukey test calculations are shown in Table 3 below,

Table 3 Summary of Tukey Test Results

\begin{tabular}{|c|c|c|c|c|c|c|}
\hline \multirow{2}{*}{ Sumber Variance } & \multirow{2}{*}{$\mathbf{n}$} & \multirow{2}{*}{$\mathbf{K}$} & \multirow{2}{*}{ Dk } & \multirow{2}{*}{ Fh } & \multicolumn{2}{|c|}{$\mathbf{F t}$} \\
\hline & & & & & $\mathbf{0 , 0 5}$ & $\mathbf{0 , 0 1}$ \\
\hline $\begin{array}{c}\text { Demonstration } \\
><\text { Ceramah }\end{array}$ & 60 & 2 & $3: 56$ & $3,13 *$ & 2,78 & 4,46 \\
\hline $\begin{array}{c}\text { MotivasiSucceed Strong } \\
\text { Demonstration } \\
><\text { Ceramah }\end{array}$ & 60 & 2 & $3: 56$ & $4,66^{* *}$ & 2,78 & 4,46 \\
\hline $\begin{array}{c}\text { MotivasiSucceed Strong } \\
\text { Demonstration } \\
><\text { Ceramah }\end{array}$ & 60 & 2 & $3: 56$ & $0,3 \mathrm{~ns}$ & 2,78 & 4,46 \\
\hline $\begin{array}{c}\text { MotivasiSucceed Strong } \\
><\end{array}$ & 60 & 2 & $3: 56$ & $5,57 * *$ & 2,78 & 4,46 \\
\hline
\end{tabular}

Information:

*: Significant **: Very significant ns: Nonsignificant 
The results of the advanced analysis using the Tukey test in table 3 above show:

The first research hypothesis states that the average knowledge about the impact of damage to coral reef ecosystems, as a whole for fishers provided with counselling by the demonstration method, is higher than the lecture method, is accepted. The mean score of knowledge about the impact of damage to coral reef ecosystems, as a whole for fishers who were given counselling by the demonstration method $=23.4$, was significantly higher than the lecture method = 21.43. The second research hypothesis states that the average knowledge about the impact of damage to coral reef ecosystems, for fishers who have strong motivation to succeed, overall the demonstration method's counselling is higher than the lecture method, is accepted. The mean score of knowledge about the impact of damage to coral reef ecosystems, as a whole, for fishers who have a strong motivation to succeed, given the counselling by demonstration method $=26.27$, which is significantly higher than the lecture method $=22.07$. The third research hypothesis states that the average knowledge about the impact of damage to coral reef ecosystems, for fishers who have weak motivation to succeed, overall the lecture method's counselling is higher than the demonstration method, is accepted. The mean score of knowledge about the impact of damage to coral reef ecosystems, as a whole for fishers has a weak motivation to succeed given the lecture method $=20.80$ higher but not significant than the demonstration method $=20.53$.

The fifth research hypothesis states that the average knowledge about the impact of damage to coral reef ecosystems, for fishers who have strong motivation to succeed overall, is higher than fishers who have weak motivation to succeed. The mean score of knowledge about the impact of damage to coral reef ecosystems, overall for fishers has a strong motivation to succeed $=24.17$, which is significantly higher than fishers who have a weak motivation to succeed =
20.66.Interview with the Pasawaran District Fishermen's Group

Interview with a fishermen group with five fishers in Pesawaran District. For information, in interviews conducted with fishermen groups in Pesawaran District, Lampung Province, fishermen groups knew and understood more about extension methods accompanied by direct demonstrations in the field. The fishermen group got more knowledge from the local government not to damage coral reefs but only limited to a prohibition from the local government and only explained that it was still limited to impacts when coral reefs were damaged but not followed by direct demonstrations. With extension research with demonstrations directly to the field, fishers will better understand and understand more about the impact of coral reef damage on the life of coastal areas with the damage to coral reef ecosystems, the life cycle that exists around coral reefs is also disrupted and will eventually break the existing food chain. So that interviews conducted with fishermen groups with extension methods followed by direct demonstrations to fishermen groups have a direct advantage over the lecture method because counselling followed by direct demonstrations in addition to increasing fishermen's understanding and also has a direct effect on environmental preservation, recovery and will have an impact on increasing tourism in Peswaran Regency, Lampung Province.

Interview with one of the Dan SatmaLanal TNI AL Lampung officials, Captain Laut Koko. Interviews were conducted with pakkokom with questions on the appropriate extension methods carried out to fishers in the Pesawaran district, Lampung about the impact of coral reef damage. In the interview conducted, Pak Kokom agreed that if the extension was carried out with direct demonstrations, it was better in the field because it would be easier for fishers to understand. Besides, fishermen will also understand more about how to restore and conserve coral reef ecosystems and fishers will also know the direct impact of damage to the coral ecosystem. coral which in turn will 
increase fishermen awareness of the importance of coral reef ecosystems. The interviews conducted at Lanal Lampung with extension methods followed by direct demonstrations to groups of fishermen have a direct advantage over the lecture method because counseling is followed by direct demonstrations besides increasing fishermen's understanding and directly affecting environmental conservation and restoration of coral reef ecosystems.

Interview with the Head of Durian Village, Pesawaran District. Interview conducted with the Head of the village of Durian, Pesawara Regency and planned to prepare tools such as bombs, cyanide, traps, muroami and boat anchors. These tools will later be used in outreach activities, where fishers are shown frequently used objects that can damage the coral reef ecosystem, (b) Identify types of coral reefs often found in fishermen's areas they live and operate fishing. This aims to determine the types of coral reefs that are good and damaged. Thus, fishers can be shown, which coral reefs are useful and coral reefs are damaged in their area.

\section{Discussion}

This study found that community support reef restoration was due to its benefits and positive impact and strongly affected by participation and knowledge about it. The analysis clearly showed that the demographic background, especially income and interaction, may affect the community's perspective. The difference between community perspectives and attitudes is mainly related to their socioeconomic demographic variables.

This over-exploitation level presents a real threat of fish populations collapsing and ecosystems, subsequently losing their ability to function. This, in turn, presents a genuine concern for the world's growing population (FAO, 2016). In Indonesia, fishery production has also been increasing steadily since 1950, and while production growth rates globally have now started to slow down to less than one percent/year,
Indonesia's growth rate continues to accelerate. Between 2003 and 2014 alone, more than 30 per cent increased production (FAO, 2016).

Good coral reefs can be seen in margins, benefits and beauty (Trialfhianty \& Suadi, 2017). Meanwhile, damaged coral reefs can be proven and can be compared with good coral reefs. By looking at the types of coral reefs from the utilization area, the beauty and damage to coral reefs that occurred in the area, it is hoped that fishers will be able to increase their knowledge about the impact of damage to coral reef ecosystems. (2020) said that fishers need to increase their knowledge, so that coral reefs are better preserved.

Besides, the findings of Wermann et al. (2019) prepared an extension plan using a demonstration method approach. Demonstration method is the ability to integrate a whole series of outreach from preliminary activities, core activities to closing activities(Basheer et al., 2017). The extension program designer is expected to integrate all extension skills, media, and literature into demonstration method activities to achieve extension objectives, increasing fishermen's knowledge about the impact of damage to coral reef ecosystems (Morzaria-Luna et al., 2014).

Provide the necessary media and learning resources. Media and learning resources are tools to achieve the goals of education or counselling. The availability of these tools allows fishers to get a concrete, deep and broad learning experience. According to Ho et al. (2016) with the demonstration method, fishers can see and try their application of knowledge, find out the advantages and disadvantages of innovation and show the effect of a treatment in the field directly.

They emphasized that the demonstration method, extension workers, and instructed methods were equally dominant during the extension process. Fishers can see and touch coral reefs directly, and discuss problems and solutions that must be taken to overcome existing problems (Dubinsky \& Stambler, 2011). The media and 
learning resources' role is crucial in the overall extension process's success from the description above. Thus the availability of media and learning resources needs to be maximized before an extension is carried out, and (e) The evaluation system is an essential aspect in the implementation of extension as it relates to measuring the extent of the success rate of the extension process (Reid et al., 2016).

The evaluation system in question is a knowledge test of the impact of damage to coral reef ecosystems: shape, type, the content of questions, and assessment techniques. The evaluation should be based on a grid arranged as a whole that represents the extension material. By developing a knowledge evaluation system about the impact of damage to coral reef ecosystems following the grid and proportionally developed extension materials, bias from extension results can be avoided. Although overall, the demonstration method is more effective than the lecture method, this study found an interaction between extension methods and fishers motivation to increase knowledge about the impact of damage to coral reef ecosystems. This shows that the planning and development of extension programs also need to pay attention to fishermen's success motivation as program recipients. For fishers who have a strong motivation to succeed it will be more effective if the extension program uses demonstration methods, while for fishers who have weak motivation to succeed it will be more emphasized using the lecture method (Tiyaningsih et al, 2020).

Efforts to Increase the Government's Role in Increasing Fishermen's Awareness in Conservation of Coral Reef Ecosystems (Widayatun, 2011). In connection with this study's results, it can be interpreted that the extension program requires the government's role to increase fishermen's awareness of the importance of conserving coral reef ecosystems. Planning extension programs using the demonstration method has crucial steps that must be taken by the government, namely (a) Preparing field extension workers who have skills related to the demonstration method so that in terms of managing the extension process they can develop and implement it according to the stated objectives, (b) Increase the budget sufficient funds to support extension activities to increase fishers' awareness to preserve coral reef ecosystems throughout Indonesia. Thus, all extension program planning can be carried out well, (c) Improve the welfare of extension workers, provide their motivation in conducting extension activities for fishers, in coastal villages throughout Indonesia, (d) Increasing extended supervision implementation. Policies implemented, both at the policy level, budget use and implementation of socialization in the field. Thus fraud can be avoided so that government objectives related to efforts to increase fishermen's awareness of the importance of conserving coral reef ecosystems can be realized, and (e) Implementation of Law no. 22 of 1999 (Undang Undang No 22 Tahun, 2009) concerning Autonomous Regional Government is a paradigm shift in development that changes the position and authority of local governments in managing the rights and obligations of their regions, including nature.

The role of coastal and small island communities as the primary users of marine resources dramatically determines the success of coral reef conservation efforts carried out through counselling and improve fishermen's qualms (Saddhono, 2017; Seytawan \& Saddhono, 2017). The quality of fishers and the benefits obtained from the activities carried out are of significant importance.

Social factors such as education and the active participation of fisher and coastal communities were crucial reasons for some reef conservation projects (Weeks et al., 2014). Many practical conservation projects and coral reef management concepts involved various community and user groups such as fishers, hotel owners, scuba divers and other coastal communities (Lowry et al., 2009), so it should be 
expected that is true for restoration as well as conservation.

\section{CONCLUSIONS}

Based on the data obtained, the results of hypothesis testing, and discussion of the research results, it can be concluded that:

1. Knowledge of the impact of damage to coral reef ecosystems as a whole for fishers who are provided with extension by demonstration methods is higher than the lecture method

2. Knowledge of the impact of damage to coral reef ecosystems for fishers who have strong motivation to succeed, extension using demonstration methods is higher than lecture methods,

3. Knowledge of the impact of damage to coral reef ecosystems for fishers who are motivated to succeed is weak, extension using the lecture method is higher than the demonstration method.

4. There is a significant interaction effect between extension methods and motivation to succeed, on knowledge about the impact of damage to coral reef ecosystems,

5. Knowledge about the impact of damage to coral reef ecosystems on fishers, as a whole for those who have a strong motivation to succeed is higher than the motivation to succeed is weak.

\section{REFERENCES}

[1] Adriman, Purbayanto, A., Budiharso, S., \& Damar, A. (2012). Analisis Keberlanjutan Pengelolaan Ekosistem Terumbu Karang di Kawasan Konservasi Laut Daerah Bintan Timur Kepulauan Riau. Jurnal Perikanan Dan Kelautan.

[2] American Counseling Association. (2015). The ACA Encyclopedia of Counseling. In The ACA Encyclopedia of Counseling. https://doi.org/10.1002/9781119221548

[3] Apuke, O. D. (2017). Quantitative Research Methods : A Synopsis Approach. Kuwait Chapter of Arabian Journal of Business and
Management

Review.

https://doi.org/10.12816/0040336

[4] Basheer, A., Hugerat, M., Kortam, N., \& Hofstein, A. (2017). The effectiveness of teachers' use of demonstrations for enhancing students' understanding of and attitudes to learning the oxidation-reduction concept. Eurasia Journal of Mathematics, Science and Technology

Education. https://doi.org/10.12973/eurasia.2017.00632a

[5] Burkepile, D. E., \& Hay, M. E. (2018). Coral reefs. In Encyclopedia of Ecology. https://doi.org/10.1016/B978-0-444-637680.00323-1

[6] Darling, E. S., McClanahan, T. R., Maina, J., Gurney, G. G., Graham, N. A. J., Januchowski-Hartley, F., Cinner, J. E., Mora, C., Hicks, C. C., Maire, E., Puotinen, M., Skirving, W. J., Adjeroud, M., Ahmadia, G., Arthur, R., Bauman, A. G., Beger, M., Berumen, M. L., Bigot, L., ... Mouillot, D. (2019). Social-environmental drivers inform strategic management of coral reefs in the Anthropocene. Nature Ecology and Evolution. https://doi.org/10.1038/s41559019-0953-8

[7] Dirhamsyah. (2018). LIPI: Status Terkini Terumbu Karang Indonesia 2018. Press Release.

[8] Dubinsky, Z., \& Stambler, N. (2011). Coral reefs: An ecosystem in transition. In Coral Reefs: An Ecosystem in Transition. https://doi.org/10.1007/978-94-007-0114-4

[9] FAO. (2016). The State of World Fisheries and Aquaculture. Contributing to food security and nutrition for all. In The State of World Fisheries and Aquaculture 2016.

[10] Farhan, A. R., \& Lim, S. (2012). Vulnerability assessment of ecological conditions in Seribu Islands, Indonesia. Ocean and Coastal Management. https://doi.org/10.1016/j.ocecoaman.2012.04. 015

[11] Fathurrohmah, S., Bunga, K., \& Marjuki, B. (2013). Aplikasi penginderaan jauh untuk 
pengelolaan hutan mangrove sebagai salah satu sumberdaya wilayah pesisir (Studi kasus di delta Sungai Wulan Kabupaten Demak). Seminar Nasional Geografi 2013, Fakultas Geografi UMS Surakarta.

[12] Fetters, M. D., Curry, L. A., \& Creswell, J. W. (2013). Achieving integration in mixed methods designs - Principles and practices. Health Services Research. https://doi.org/10.1111/1475-6773.12117

[13] Gelso, C. J. (2015). Counseling Psychology. In International Encyclopedia of the Social \& Behavioral Sciences: Second Edition. https://doi.org/10.1016/B978-0-08-0970868.21073-8

[14] Gittenberger, A., Draisma, S. G. A., Arbi, U. Y., Langenberg, V., Erftemeijer, P. L. A., Tuti, Y., \& Hoeksema, B. W. (2015). Coral reef organisms as bioregion indicators off Halmahera, Moluccas, Indonesia. Aquatic Conservation: Marine and Freshwater Ecosystems. https://doi.org/10.1002/aqc.2495

[15] Hole, Y., \& Snehal, P. \& Bhaskar, M. (2018). Service marketing and quality strategies. Periodicals of engineering and natural sciences, 6 (1), 182-196.

[16] Hole, Y., \& Snehal, P. \& Bhaskar, M. (2019). Porter's five forces model: gives you a competitive advantage. Journal of Advanced Research in Dynamical and Control System, 11 (4), 1436-1448.

[17] Ilahude, A. G., \& Gordon, A. L. (1996). Thermocline stratification within the Indonesian Seas. Journal of Geophysical Research C: Oceans. https://doi.org/10.1029/95JC03798

[18] Lesser, M. P. (2004). Experimental biology of coral reef ecosystems. Journal of Experimental Marine Biology and Ecology. https://doi.org/10.1016/j.jembe.2003.12.027

[19] Lowry, G. K., White, A. T., \& Christie, P. (2009). Scaling up to networks of marine protected areas in the Philippines: Biophysical, legal, institutional, and social considerations. Coastal Management. https://doi.org/10.1080/08920750902851146

[20] Mohan, R. K. (2005). Capping of contaminated coastal areas. In Encyclopedia of Earth Sciences Series. https://doi.org/10.1007/1-4020-3880-1_59

[21] Morzaria-Luna, H. N., Turk-Boyer, P., \& Moreno-Baez, M. (2014). Social indicators of vulnerability for fishing communities in the Northern Gulf of California, Mexico: Implications for climate change. Marine Policy. https://doi.org/10.1016/j.marpol.2013.10.013

[22] Nadiarti, N., Riani, E., Djuwita, I., Budiharsono, S., Purbayanto, A., \& Asmus, H. (2012). Challenging for Seagrass Management in Indonesia. Journal of Coastal Develpopment.

[23] Narwan, Y. (2019). Penentuan Zonasi Ruang Laut Dan Pesisir Kabupaten Natuna Sebagai Arahan Pemanfaatan Sumberdaya Kelautan Dan Pesisir Dalam Upaya Pengembangan Kawasan Strategis Nasional. Journal of Chemical Information and Modeling. https://doi.org/10.1017/CBO9781107415324. 004

[24] Nasution, R. D. (2017). Pengaruh Perkembangan Teknologi Informasi Komunikasi Terhadap Eksistensi Budaya Lokal. Jurnal Penelitian Komunikasi Dan Opini Publik.

[25] Paradis, E., O’Brien, B., Nimmon, L., Bandiera, G., \& Martimianakis, M. A. T. (2016). Design: Selection of Data Collection Methods. Journal of Graduate Medical Education. https://doi.org/10.4300/JGME-D16-00098.1

[26] Petzold, J. (2018). Social adaptability in ecotones: Sea-level rise and climate change adaptation in flushing and the isles of scilly, UK. Island Studies Journal. https://doi.org/10.24043/isj.17

[27] Planes, S., Allemand, D., Agostini, S., Banaigs, B., Boissin, E., Boss, E., Bourdin, G., Bowler, C., Douville, E., Flores, J. M., Forcioli, D., Furla, P., Galand, P. E., 
Ghiglione, J. F., Gilson, E., Lombard, F., Moulin, C., Pesant, S., Poulain, J., ... Zamoum, T. (2019). The Tara Pacific expedition-A pan-ecosystemic approach of the "-omics" complexity of coral reef holobionts across the Pacific Ocean. In PLoS Biology.

https://doi.org/10.1371/journal.pbio.3000483

[28] Ponticelli, C., \& Graziani, G. (2012). Education and counseling of renal transplant recipients. Journal of Nephrology. https://doi.org/10.5301/jn.5000227

[29] Reid, H., Bimrose, J., \& Brown, A. (2016). Prompting reflection and learning in career construction counseling. Journal of Vocational Behavior. https://doi.org/10.1016/j.jvb.2016.07.013

[30] Saddhono, K. (2017). Language of coastal communities in the northern coast of central java: sociolinguistic studies in cultural integration maritime-agrarian perspective. Advanced Science Letters, 23(10), 1005410056.

[31] Setyawan, B. W., \& Saddhono, K. (2017). Eret traditional ceremony as representation of spirit of mutual cooperation among coastal communities. Advanced Science Letters, 23(10), 9991-9992.

[32] Spalding, M. D., Ruffo, S., Lacambra, C., Meliane, I., Hale, L. Z., Shepard, C. C., \& Beck, M. W. (2014). The role of ecosystems in coastal protection: Adapting to climate change and coastal hazards. Ocean and Coastal Management. https://doi.org/10.1016/j.ocecoaman.2013.09. 007

[33] Sutton-Grier, A. E., Wowk, K., \& Bamford, H. (2015). Future of our coasts: The potential for natural and hybrid infrastructure to enhance the resilience of our coastal communities, economies and ecosystems. In Environmental Science and Policy. https://doi.org/10.1016/j.envsci.2015.04.006

[34] Tiyaningsih, T., \& Suyitno, Saddhono, K. (2020). Sustainable Technology in Marine
Fisheries in Cilacap Regency, Central Java, Indonesia. Journal homepage: http://iieta. org/journals/ijdne, 15(3), 401-407.

[35] Thanigaivel, S., Chandrasekaran, N., Mukherjee, A., \& John Thomas. (2016). Seaweeds as an alternative therapeutic source for aquatic disease management. In Aquaculture.

https://doi.org/10.1016/j.aquaculture.2016.08. 001

[36] Trialfhianty, T. I., \& Suadi. (2017). The role of the community in supporting coral reef restoration in Pemuteran, Bali, Indonesia. Journal of Coastal Conservation. https://doi.org/10.1007/s11852-017-0553-1

[37] Undang Undang No 22 Tahun. (2009). UU No 22 Tahun 2009. UU No. 22 Th 2009.

[38] Van Oppen, M. J. H., Oliver, J. K., Putnam, H. M., \& Gates, R. D. (2015). Building coral reef resilience through assisted evolution. In Proceedings of the National Academy of Sciences of the United States of America. https://doi.org/10.1073/pnas.1422301112

[39] Voleti, S. (2019). Data Collection. In International Series in Operations Research and Management Science. https://doi.org/10.1007/978-3-319-68837-4_2

[40] Wallace, R. B., Baumann, H., Grear, J. S., Aller, R. C., \& Gobler, C. J. (2014). Coastal ocean acidification: The other eutrophication problem. Estuarine, Coastal and Shelf Science. https://doi.org/10.1016/j.ecss.2014.05.027

[41] Wardhani, M. K. (2011). Kawasan Konservasi Mangrove: Suatu Potensi Ekowisata. Jurnal Kelautan. https://doi.org/https://doi.org/10.21107/jk.v4i 1.891

[42] Weeks, R., Aliño, P. M., Atkinson, S., Beldia, P., Binson, A., Campos, W. L., Djohani, R., Green, A. L., Hamilton, R., Horigue, V., Jumin, R., Kalim, K., Kasasiah, A., Kereseka, J., Klein, C., Laroya, L., Magupin, S., Masike, B., Mohan, C., ... White, A. T. (2014). Developing Marine 
Protected Area Networks in the Coral Triangle: Good Practices for Expanding the Coral Triangle Marine Protected Area System. Coastal Management. https://doi.org/10.1080/08920753.2014.8777 68

[43] Wermann, J., Colombo, A. W., Pechmann, A., \& Zarte, M. (2019). Using an interdisciplinary demonstration platform for teaching Industry 4.0. Procedia Manufacturing. https://doi.org/10.1016/j.promfg.2019.03.048

[44] Widayatun. (2011). Peran masyarakat dalam pelestarian terumbu karang dan dampaknya terhadap peningkatan kesejahteraan. Jurnal Kependudukan Indonesia, VI(2), 1-19. http://ejurnal.kependudukan.lipi.go.id/index.p hp/jki/article/download/91/137

[45] Yasir, Y., Nurjanah, N., \& Yesicha, C. (2017). A Model of Communication to Empower Fisherman Community in Bengkalis Regency. MIMBAR, Jurnal Sosial Dan Pembangunan. https://doi.org/10.29313/mimbar.v33i2.2135

[46] Yogesh Hole et al 2019 J. Phys.: Conf. Ser. 1362012121 